\title{
Sustainable Urban Streetscape: Managing trees as green infrastructure
}

\author{
Nor Syafiqah Zairuddin ${ }^{1}$, Noriah Othman ${ }^{2}$, \\ Nurhayati Abdul Malek ${ }^{3}$
}

\begin{abstract}
${ }^{1}$ Center of Studies for Postgraduate, Faculty of Architecture, Planning \& Surveying, UiTM, Malaysia 40450 Shah Alam, Selangor, MALAYSIA. ${ }^{2,3}$ Center of Studies for Landscape Architecture, Faculty of Architecture, Planning \& Surveying, UiTM, Puncak Alam Campus, 42300 Bandar Puncak Alam, Selangor, MALAYSIA.
\end{abstract}

norsyafiqahz03@gmail.com ,noriaho@yahoo.com,nurhayati8203@uitm.edu.my

\begin{abstract}
Green and grey infrastructure plays a significant role in exposing the quality to the urban streetscape. The establishment and post-execution of streetscape planting management practice become a marking factor in measuring the sustainability of roadside tree planting. Due to the acceleration of the urbanization, conflicts in growing healthy roadside tree planting keep arising. Hence, this study is to deliver a discussion of nonnumerical data on the potential attributes and approaches that can be adopted and adapted in Malaysia for a better quality of streetscape tree planting practices.
\end{abstract}

Keywords: Streetscape Design; Roadside Tree Planting; Tree Sensitive Urban Design Theory

eISSN 2398-4295 @2020. The Authors. Published for AMER ABRA cE-Bs by e-International Publishing House, Ltd., UK. This is an open access article under the CC BY-NC-ND license (http://creativecommons.org/licenses/by-nc-nd/4.0/). Peer-review under responsibility of Association of Malaysian Environment-Behaviour Researchers (AMER); Association of Behavioural Researchers on Asians / Africans / Arabians (ABRA); Centre for Environment-Behaviour Studies (cE-Bs), Faculty of Architecture, Planning \& Surveying, Universiti Teknologi MARA, Malaysia DOI: https://doi.org/10.21834/ajbes.v5i19.193 


\subsection{Introduction}

Comprehensive and intangible reinforcement by green infrastructure may lead the streetscape to furnish a conducive environment to the users. In term of theoretical factor, developing successful streetscape design include the consideration on the availability of space, setback, hardscape and footpath clearance, service constraint, liability, and public safety. Environmentally, disregarding these key factors will deteriorate the quality of air and the sequestration of carbon dioxide. The unhealthiness of roadside trees always brings the risk to road users due to its lower rate of durability. Exploring a practical and feasible approach in sustaining roadside tree planting will ensure the internal cycle of inputs by the roadside tree, and the outputs through its benefits consistently support the quality of life (QOL) in Malaysia's rapid urbanization development. The development of the city is to balance with the green fabrics where the National Landscape Department (NLD) itself has issues National Landscape Policy. The intention is to ensure Malaysia as a Beautiful Garden Nation by 2020. Over NLD, the Ministry of Housing and Local Government has worked on evolving sustainable green infrastructure in Malaysia. This effort will help to improve the quality of life of people by establishing a conducive, healthy, and pleasant quality environment (National Landscape Policy, 2011).

A comprehensive tree planting in bringing greenery into the grey forest through the initial program of 'No Roads Without Trees' become hugely successful (Kadir \& Othman, 2012). However, the aim of putting the quantity over quality has created many issues on roadside tree planting. Unaware of sustainable methods in growing healthy trees, thus resulting in trees to deliver negative outputs than its supposed target to balance with the cities' concrete infrastructure. Hence, the aim of this paper is specifically at all levels of hierarchy, including government, professional sector, academia, and community. It is because the prospective benefits of urban streetscape tree planting are often sustained by the existence of scheme conditions, which in comprehend with the tree maintenance level, values of the public, policies by local and authorities, as well as the structure and density of the surrounding built form (Hale et al., 2015).

This study concern with the ability of roadside tree planting in contributes yet delivers the benefits to the community, environment, and economy both internally and physically. It will also include modification of climate, enhancement of air quality, habitat for urban wildlife, aesthetics, (Karuppannan et al., 2014), moderate stormwater runoff (Saraswat et al., 2016), and others (Kanniah and Ho, 2017). In achieving the benefits, site planning standards, along with adequate knowledge of tree selection practices and strict consideration on tree quality standards, are the resolutions to this goal. Likewise, approaches to best practice need to be investigated comprehensively (Pauleit, 2003). In Malaysia, there are still no official guidelines or documents that individually advise on tree maintenance, especially on roadside trees. Appropriate management and maintenance of the urban tree planting will help to assure trees become healthy, resilient, and can survive for the long-term, thereby reducing the maintenance burden. Hence, the main objective of this paper is to accumulate and present an approach that can resolve roadside tree planting issues in streetscape design, yet improving communities' quality of life. 


\subsection{Literature Review}

\subsection{Dilemma in Sustaining Tree Planting at Urban Streetscape}

Street trees face an extremely hostile environment in the city and may struggle to survive and grow (Ow and Ghosh, 2017; Ghosh et al., 2016). Most of the time, trees have long been fit into spaces left over after everything else is written into the design. This approach will not work if we want the trees to be the most significant element in the city's structure. Green infrastructure plays a crucial role in ensuring the quality of life in urban areas remains functional. Over the years ago, green space within the cities plays a position as an urban lung, discharging oxygen to reduce the heat of the city, and the wall for harmful air pollution (Anguluri \& Narayanan, 2017). Nevertheless, despite the benefits offered by the green space to the enhancement of the city environment, rapid urban development has led to the destruction of green space and driving the city unsustainable (Nur Syafiqah et al., 2018). By way of example, shade provided by the tree that undergoes the transpiration process enables the benefit to be delivered to both people and the infrastructure by functioning as a cooling factor. Nevertheless, this factor may be disturbed by the situations where the hard surfaces will reduce the level of soil moisture, and even the built infrastructure may slowly damage the tree roots. Figure 1 below shows the conflicts that arise from current rapid urbanization.

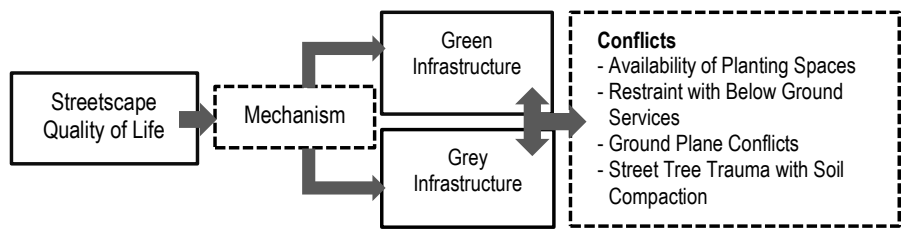

Figure 1: Conflicts that influence Streetscape Quality of Life

(Source: Author)

\subsubsection{Availability of Planting Spaces}

Limited spaces for tree planting to grow always caused by the issue of road widening and construction of a new road (Lazim \& Misni, 2016). Demand in the broader road to support increasing numbers of vehicles on roadside thus lead green space to be sacrificed without think far ahead. Thomson and Sorvig in 2000 clarified that over the past century, specifications on conventional tree planting attend to be more concerned about crushing trees into minimum space rather than allowing plants to thrive. A buildable area for people and vehicles always demands by clients in enabling it in maximum space, which thus left a very minimum plantable space. There is still competition within the road corridor for available space in dividing it into a different range of functional and physical uses such as car parking, traffic lanes, bicycle lanes, and bus lanes. Apart from that, there is also a competition within the verge space for property access, pedestrian circulation, signage, and street furniture. Both above and below ground space also undergo competition from engineering infrastructure that includes street and pedestrian lighting, traffic control devices, overhead powerlines, stormwater drainage, and below-ground services, including sewerage, water supply, and electricity (Ely, 2010). 


\subsubsection{Below Ground Services}

Both Common Services Trench (CST) and Sewer Line made up of underground services. These services always become a conflict to the planting area as, at most of the situation, it has frequently been locating at landscape area, which indirectly created an issue in thriving green infrastructure towards a better quality of its output yet reducing the significant impact on the quality of life. There is no evidence to convince that both trees and underground services do not coexist together. Most of these underground services been located and installed at the plantable area in which trees could be severely damage whenever roots need to be cut to excavate and repair the facilities. Not only services, direct contact of tree roots with lightweight structures such as boundary wall also can even destruct its wall footing which at last negatively affect both root and the structure (Hasan et al., 2018).

\subsubsection{Hardscape Conflicts}

Kerb is a narrow hardscape element that inappropriate of its implementation will cause damage to both curb and roadside tree roots. A separation at a minimum of $1300 \mathrm{~mm}$ of curb setbacks is needed between tree centreline and curb face. It will prevent damage of tree root to the curb and road pavement. In terms of walkway setbacks, a separation of minimum $1000 \mathrm{~mm}$ is required from trees to walkway in minimizing tree root damage to the walkway. This intention is to clear and unobstructed pedestrian access (PUAC,1997). However, the competition in splitting up one definite space into different functional space just lead the landscape to be given a little space that left last. Most of the roadside planting space, especially on the median planting, has been provided with a maximum 1-meter end to end width, which means the length between the curb face and centerline of the tree is only $500 \mathrm{~mm}$.

\subsubsection{Soil Compaction trigger Trauma to Street Tree}

According to Roberts et al. (2006), soil compaction results from human activities associated with urban development. The result can be either intentional or unintentional. Severe compaction usually causes by construction activities, especially on intentional compaction. It is to prevent uneven soil settlement below pavements and building footings. Maximum bulk densities aimed by the engineers as possible it is. It achieved when the moisture content of soils is at their optimum level. The engineers have used the Proctor test used in determining maximum bulk densities for soils and optimum water content for compaction. In the specification, soil commonly requires its maximum bulk density to be compacted to $95 \%$. However, soil compaction can also be unintentional. The compaction happened due to the loading of vehicular or pedestrian traffic that brings into soil compaction. Besides, this unintended but severe compaction also occurs during site construction. Activities such as material storage and vehicle movement lead to this conflict, too (Roberts et al., 2006).

\subsection{Review of Practices: Malaysia vs Singapore}

In Malaysia, both the National Landscape Department (NLD) and the Department of Urban and Rural Planning Malaysia (NURPD) have provided general guidelines in preparing yet designing street tree planting (NLD, 2011; JPBD, 2010). These include the requirement of minimum planting 
width and suggestion of suitable planting species. However, in comparison with Singapore Greenery Provision for Roadside (ND, 2018), Malaysia is still lacking on some technical requirements of growing roadside tree planting. These have been summarized in Table 1 below.

Table 1: Comparison of Tree Planting Guideline

\begin{tabular}{ccc}
\hline $\begin{array}{c}\text { Malaysia Tree Planting } \\
\text { Guideline }\end{array}$ & Practices & $\begin{array}{c}\text { Singapore Tree Planting } \\
\text { Guideline }\end{array}$ \\
\hline$\sqrt{ }$ & Planting Width & $\sqrt{ }$ \\
\hline & Planting Selection & $\sqrt{ }$ \\
\hline$x$ & Technical requirement: \\
$\sqrt{ }$ & i. Aeration requirement \\
$x$ & ii. Soil Mixture Specification & $\sqrt{ }$ \\
& iii. Clearance of Proposed & $\sqrt{ }$ \\
\hline
\end{tabular}

(Source: Author)

Compared to Malaysia, Singapore did provide much detail and specific technical requirements for its roadside greenery provision, especially on the clearance of proposed roadside elements, which always become one of the factors that lead to roadside tree planting conflict. Apart from that, roadside tree planting condition in every country and town in Malaysia also tend to have different in quality as different authority conducts management and maintenance for the separate area.

\subsection{Methodology}

Presently, this research was about the progress of obtaining secondary findings. As a consequence, this paper was representing on non-numerical data where information was being collected by reviewing related journals. The journals were selected to correlate with the research field and about four main categories included, which are Social Science, Environmental Research, Science Direct, and Google Scholar. The relevant journal was found by searching on related keywords such as roadside tree planting, streetscape design, quality of life, and tree management. Subsequently, the conflicts on current roadside tree planting, theory, and guideline that associated with research study were identified.

\subsection{Findings and Discussion}

The author's previous study has highlighted the overall theory of Tree Sensitive Urban Design by Ely (2010) that comprise of two principles. The principles include both structural and nonstructural principles, and theoretically, these two principles are just complemented enough in developing best roadside tree management practices. However, this study will only review indepth on a few practical attributes that convenient with the Malaysian context. Overall, the findings of the study are then to be divided into two parts: Tree Establishment Practice and Post Execution Practice. 


\subsection{Tree Establishment Practice}

High resilience of urban roadside tree planting is linked by two general factors, which classified by tree health and suitability (Madalena et al., 2019). Suitability factor is interpreted by the planting design and on how its tree planting selection contributes towards the permanent green structure. In addition to that factor, tree health subsequently plays the other key important factor in tree establishment practice. For that reason, the attributes come out as summarized in Table 2 below will stress on all the elementary sub-factors of establishing healthy streetscape trees.

Table 2: Attributes in Establishing healthy Streetscape trees

\begin{tabular}{|c|c|c|}
\hline Elements & Explanation & Source \\
\hline Plant Material Preferences & $\begin{array}{l}\text { To avoid species that will contribute to the } \\
\text { conflicts and to select tree as in following } \\
\text { the site condition }\end{array}$ & $\begin{array}{l}\text { Castello \& Jones (2003), Thomas } \\
\text { (2016), Hasan et al. (2016), } \\
\text { Harris et al. (2014) \& Hasan et al. } \\
\text { (2018) }\end{array}$ \\
\hline Rooting Environment & $\begin{array}{l}\text { Improving the rooting environment by using } \\
\text { root barrier and structural soil }\end{array}$ & $\begin{array}{l}\text { Morgenroth (2008), Day et al. } \\
\text { (2010), Paganová (2016), Ow } \\
\text { and Gosh (2017), Grabosky and } \\
\text { Bassuk (2016) }\end{array}$ \\
\hline Tree Pit Design & $\begin{array}{l}\text { To plant the trees at adequate volume with } \\
\text { appropriate planting method }\end{array}$ & $\begin{array}{l}\text { Leers et al. (2018), Craul \& Crau } \\
\text { (2006), Balsamo (2008) }\end{array}$ \\
\hline Extended Rooting Space & $\begin{array}{l}\text { Suggestion on methods in providing } \\
\text { enough soil volume for root growth stability }\end{array}$ & $\begin{array}{l}\text { Day et al. (2010), Hasan et al. } \\
\text { (2016), Ely (2010), Costello et al. } \\
\text { (2000), Jason et al., } 2002\end{array}$ \\
\hline Tree Pruning & $\begin{array}{l}\text { Highlighting the importance of the } \\
\text { appropriate method of pruning in preventing } \\
\text { any injuries that will invite decay organisms } \\
\text { and bacteria }\end{array}$ & $\begin{array}{l}\text { Bobrowski et al. (2017), } \\
\text { Skovsgaard et al. (2018) }\end{array}$ \\
\hline
\end{tabular}

\section{Attribute 1: Plant Material Preferences}

'Right Tree at the Right Place' has always been recommended in reducing tree conflicts with the infrastructure. It is by selecting the proper size of the tree to fit the planting space. Thomas, in his study in 2016, explained that public outages and roadside maintenance costs could be reduced when the right tree at the right place is being applied. As a result of this practice, the picturesque of scenic roads may be conserved. Plant Material preferences could be done by not selecting species that have characteristics to create a conflict with the infrastructure (Castello \& Jones 2003). In achieving successful roadside landscape management, the method of choosing native or introduced tree species is applicable as long the growing requirements and elements fit both living and non-living structures. Different types of road referred; highway, protocol road, primary road, secondary road, and back lane are being classified according to its widths. Due to this, the selection of tree species with appropriate trees character should be considered as a different type of road with different widths have different conditions of the environment (Hasan et al., 2018). Apart from that, one of the critical parts is to avoid species that have a higher potential in bringing damage to the other nearest element. These elements include a plant that has root buttress, massive trunk flare, and those with roots that tend to grow at the surface of the soil. In consequence of arising roadside tree planting conflicts, many arborists concede that tree selection is essential in minimizing conflicts between both pavement and tree (Harris et al., 2004). 
Survey outcome conducted by Hasan et al., (2016) identified that the level of knowledge in selecting tree species in Malaysia is still at a low level. This matter arises when the aesthetical value has been prioritized more than its appropriateness. A thing that they need to realize is an attractive tree planting is possible delivered by appropriate tree selection. In doing so, trees can grow well, which in consequence contributes to giving a healthy scenic green structure.

\section{Attribute 2: Rooting Environment}

Environmental sustainability may be influenced by soil environment through the exploration of tree root towards drainage and soil structure (Day et al., 2010). However, the amount of repairing broken pavement and other hardscape elements caused by tree roots keep arising. This conflict has happened when the urban space allows just too little plantable space for tree root systems to develop and survive naturally. Apart from that, the conflicts of arising root damage also caused by the unawareness of biological requirements during the establishment and operational stage (Paganová, 2016). As because of that, damage to nearby non-living infrastructure is expected. In these practices, selected methods involved are the use of root barriers and structural soil (Morgenroth, 2008). Installation of surround-type root barriers is often specified as a means of preventing damage from future root growth when a new street or parking lot trees been planted. While surrounding a newly-planted tree's root ball, the root barrier may become one of the ideal solutions in these root-space limited sites. Other than that, the use of structural soils also becomes another choice for good quality rootzone practice. Ow and Gosh (2017), in their study explained that the used of structural soil might enhance about $50 \%$ of root colonization. Besides, it can improve soil quality and even capable of increase the volume of soil. The used of structural soil system will help in providing substrate for root growth that is advantageous to both above- and below-ground zone of trees growth even with the mix of stone is high in proportion (Ow and Gosh, 2017). Grabosky and Bassuk (2016) in their 17 years growth in structural soil study showed that trees sustain longer when grown in structural soil compared to trees grown in a lawn. It is proved that structural soil becomes as one of the cost-effective methods in planting a tree at limited space (Ow and Gosh, 2017).

\section{Attribute 3: Tree Pit Design}

Commonly, roadside tree planting conflict occurred by inappropriate of its planting technique. The performance and establishment of a street tree are affected by planting advanced stock either too profoundly or more rarely too shallow. It has been a subject of concern for a decade, and these conflicts cause by simple offence should no longer arising. Besides, a lot of latest studies have verified that about $25 \%$ of specific street tree plantings have not yet planted at adequate depth (Leers et al., 2018). Planting depth specifications are usually quite clear, but too often, they are not enforced. A particular design solution is required to ensure a constraint tree pits in the urban area that surrounded by hard paved surfaces can deliver its benefit at the optimum level. A few practitioners and researchers have identified current 'best practices' based on the biological 
requirements of trees (Craul \& Crau, 2006; Balsamo, 2008). These requirements are as listed below.

a. Excavate the hole approximately three times larger than the root ball.

b. Avoid vertical pit walls, but rather flare the walls out in a 'wok' shape to increase the size of the mulched opening.

c. The root ball should be placed on a firm surface to avoid future settling and risk of collar rot.

d. Roughen the tree pit walls if they are smoothed during excavation, to facilitate root penetration.

e. Provide adequate drainage by breaking through any compacted layers, or installing under drainage. As a guide, the tree pit can be filled with water, and the rate of drainage observed.

f. Backfill with the original unamended soil removed from the tree pit.

g. Slope backfills upwards from the trunk to create a watering bowl.

h. Cover with mulch to the recommended thickness, leaving a space between the trunk and mulch to avoid collar rot.

\section{Attribute 4: Extended Rooting Spaces}

The ability of urban trees root system in acquiring resources and anchorage becomes a factor of its growth performance (Day et al., 2010). Hence, in ensuring the roadside tree to have enough stability and the ability to grow at its optimum size, the root tree system must be provided with sufficient soil volume. Hasan et al. (2016), in their study, found that about $56.5 \%$ of the public agreed that planting space provided for roadside tree planting is not suitable and insufficient. There is an applicable method to reduce the conflict, there is an applicable method named extending rooting areas (Ely, 2010). It can be categorized as shared rooting volume, tree islands, and linear tree pits. The value of creating 'shared rooting volumes' has been stressed by a few authors recently. The purpose is to create a much larger space for planting by putting a group of trees together in one more extensive area (Ely, 2010). Moreover, tree pits also can be interconnected with a form called 'soil trench'. Previous studies by Urban in 1996 suggests that two trees will grow larger when planted in a particular soil volume compared to a single tree with half that volume. Large common tree planting pits can be created when space exists in broad open medians or verges (Costello et al., 2000). Besides, planting arrangement through 'tree island' and geometry planting are the other best approach (Urban, 1996 and Ely, 2010). Tree island is formed by categorizing the areas that can plant several trees in a large pit with its soil volume is to be shared. The benefit of applying large areas and volumes of planting media is to allow much more effective management of soil nutrient and compaction, oxygen, and water status. Same goes to planting tree in geometry form, shared rooting volumes will provide large pit for trees to grow. Additionally, the other best solution is to create a 'linear tree pits'. In other terms, it is yet known as 'soil trenches', 'continuous trenches' and 'root trenches'. The main intention of connecting tree pits by an open verge, or by connecting tree pits beneath pavements is to utilize structural soils; in Attribute 3 as a support to the pavement. With the definition as a mixture of a stone matrix for strength and soil for horticultural needs, the stone lattice is the component used in structural soil as one of the medium to support the pavement (Jason et al., 2002). 


\section{Attribute 5: Tree Pruning}

Trees critically need to undergo a proper pruning method in acquiring good health condition, tree structure clearance for safety and aesthetic values, while promoting life. Unfortunately, improper pruning can even be one of the terrible things that can drive the tree to confront with wounds. The process of recovering take place very slowly, depending on the size of the cut and the health of the trees (Bobrowski et al., 2017). Pruning with the improper method will bring an opening for the insects, which indirectly allow the trees to get infected. As a consequence, it will adversely affect the strength and health of the tree. Selecting appropriate tree species for specific critical locations can shorten the need for pruning, which indirectly reducing the cost for pruning. Several types of pruning methods are to be implemented following different demands and situations. Topping is the indiscriminate cutting back of tree branches to stub the branches that are not large enough to assume the terminal role. This type of pruning method is to prevent interference with overhead utility lines. Unfortunately, topping can cause injury in trees in various ways. Usually, trees that are topped produce vigorous water sprouts, which often grow back to their original height to become denser at a faster rate. Water sprouts from the topped portion tend to have weak attachments with the main trunk, making the branches weak. It is crucial to make proper cuts when pruning trees. It is due to that flush cuts will produce large wounds, hence cause it to heal slowly (Skovsgaard et al., 2018). Thus, it exposes the wound to decay organisms. Branches that are appropriately pruned, generally have a circular closure around the wound. Branches that are cut carefully to the trunk, on the contrary, will result in the closure of callus, either be oval or distorted. Injuries that are not closed by callus will invite decay organisms and bacteria to invade the tree, which will then further weaken the tree structure.

Table 3: Attributes for Tree Establishment Practice in Tree Sensitive Urban Design (TSUD)

Tree Sensitive Urban Design (TSUD) Theory

\begin{tabular}{|c|c|c|c|c|}
\hline \multicolumn{5}{|c|}{ Establishment Practice } \\
\hline $\begin{array}{c}\text { Tree Selection Based } \\
\text { Practice }\end{array}$ & $\begin{array}{c}\text { Root Zone Based } \\
\text { Practice }\end{array}$ & $\begin{array}{l}\text { Tree Pit } \\
\text { Design } \\
\text { Practice }\end{array}$ & Extended Rooting Spaces & $\begin{array}{l}\text { Proper } \\
\text { Pruning }\end{array}$ \\
\hline $\begin{array}{r}\text { - 'Right Tree at the } \\
\text { Right Place' }\end{array}$ & $\begin{array}{l}\text { - Structural Soil } \\
\text { - Root Barrier }\end{array}$ & & $\begin{array}{l}\text { - Shared Rooting Volumes } \\
\text { - Tree Island/Geometry } \\
\text { Planting } \\
\text { - Linear Tree Pit }\end{array}$ & \\
\hline
\end{tabular}

\subsection{Post Establishment Practice}

Several approaches have been justified to support the trees physically during tree establishment practice. Aside from that, the execution on post establishment of the urban roadside tree plays a critical stage to ensure the longevity of the tree. The step involves three types of management that are establishing, maintaining, and removing trees. In other words, roadside tree management is about the process of minimizing the hazard by doing the inspection and mitigation. This process is to balance the level of risk while able to maintain its beautiful trees structure on-site (Hasan et al., 2016). In achieving the long term of growing healthy trees, these three approaches should be applied. The main priority in managing the roadside tree is to remove hazardous trees or some 
of its dangerous parts. It is to ensure the safety of people while using the road. The other most crucial stage reported in tree pruning activity. However, this tree maintenance activity is stated as the most harmful and costly activity (Murad, 2000). Unfortunately, Hasan et al., (2016), in his findings, found that the majority of $93.5 \%$ of the public agreed that maintenance workers did use personal protection equipment (PPE) during the tree maintenance process. The organization within tree management itself plays a crucial part in ensuring optimum quality of roadside tree planting. The deficiency of training facilities and opportunities between employees has resulted in various problems causing hazardous trees cannot be managed effectively. Another harmful and costly urban problem is related to wood-decay fungi diseases. This problem will burden the urban tree on its many years of wood-decay builds up, hence cause tree fall conflict to arise (Lüttge \& Buckeridge, 2020). However, inadequate or even minimum space that left for planting bring some practitioner to plant the tree without putting extra concern on how to sustain the tree with this on-site limiting factors. The understanding of how to manage the roadside green structure and the way to optimize the potential benefits to the broader scope is needed to be appreciated by all parties involved, which is another way of saying, an interdisciplinary collaboration. It includes the policymakers, planners, authorities, consultants, contractors, and even the public. Their contribution to delivering the understanding through effective communication and discussion among them will allow the positive outcome of urban green structure to integrate as a whole. Figure 3 below shows the overall concept of tree establishment practice.

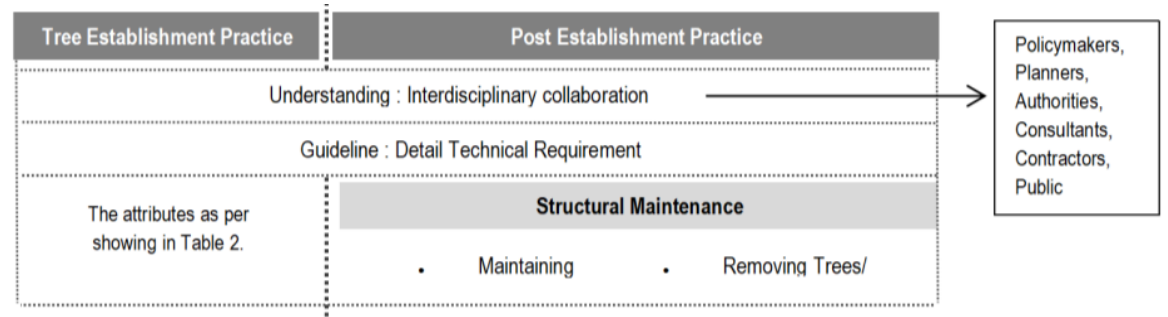

Figure 3: Overall Concept of Tree Establishment Practice

(Source: Author)

\subsection{Conclusion}

The purpose of this study is to review the possible attributes to be adapt and adopt in Malaysia Roadside Tree Planting Guideline. The nowadays congested structural environment has led the author to prioritize the study on the crucial conflicts that involve roadside tree planting. The issues classified from the study, thus bring the author to analyze the potential attributes in bringing current Malaysian roadside tree planting towards better quality guidelines. The guidance on this roadside tree planting comprises of three different planting zones that are below the ground zone, ground plane, and above the ground zone. The vital part in sustaining the quality of the tree is the below-ground zone as most of the conflicts have come from this zone. For that reason, the potential attributes in rectifying the conflict are by concentrate on its root zone based practices, tree pit design practices, and the extended rooting spaces. Both ground plane and above ground 
zone are the perceive parts where its circumstances can be observed forthrightly. Selecting appropriate tree species and applying the good and right pruning method has been the most exceptional practice in resolving the conflicts at these zones. Despite bringing the quality of the visual context, both tree selection and pruning process also have an impact on how it can sustain long-lasting in delivering the quality to the society and environment. It is expected that the awareness of the essential methods in ensuring the sustainability of roadside tree planting will be considered by others, especially the authorities. The reason is that their role in ensuring roadside tree planting enables to deliver its benefit at the best level is hugely substantial.

\section{Acknowledgement}

This study was made possible by the continuous support from IRMI, Universiti Teknologi MARA for providing the funding support through the Research Grant Dana Universiti Cawangan Selangor DUCS 2018 600-UiTMSEL (PI. 5/4) (057/2018).

\section{References}

Anguluri, R., \& Narayanan, P. (2017). Role of Green Space in Urban Planning: Outlook Towards Smart Cities. Urban Forestry \& Urban Greening, 25, 58-65. https://doi.org/10.1016/j.ufug.2017.04.007

Balsamo, D. (2008). Planting Trees in Urban Situations for South Eastern Australia. Melbourne, Victoria, Treelogic.

Bobrowski, R., Zamproni, K., Maria, T. R. B. D. C., \& Biondi, D. (2017). Variability and Balance of Crown Projection of Trees Planted on Sidewalks of Three Brazilian Cities. Cerne, 23(3), 321-327.

Costello, L.R. and K.S. Jones (2003). Reducing Infrastructure Damage to Trees: A Compendium of strategies. Cohassat, $\mathrm{CA}$, Western Chapter of the International Society of Arboriculture.

Costello,L.R., E.G. McPherson, D.W. Burger and L.L. Dodge (2000). Strategies to Reduce Infrastructure Damage by Tree Roots: Proceedings of a Symposium for Researchers and Practitioners, Cohassat, CA, Western Chapter, International Society of Arboriculture.

Craul, T.A. and P.J.Craul (2006). Soil Design Protocols for Landscape Architects and Contractors. Hoboken, New Jersey, John Wiley \& Sons Inc.

Day, S. D., Wiseman, P. Er., Dickinson, S. B., and Harris, J. R. (2010). Tree Root Ecology in the Urban Environment and Implications for a Sustainable Rhizosphere. Arboriculture \& Urban Forestry. 36(5): 193-205

Ely, M. E. (2010). Integrating Trees into the Design of the City: Expert Opinions on Developing More Sustainable Practices for Planting Street Trees in Australian Cities. Climate Change 2013 - The Physical Science Basis, (September), 1-30. https://doi.org/10.1017/CB09781107415324.004

Ghosh, S., Scharenbroch, B., Burcham, D., \& Mahimairaja,S. (2016). Influence of Soil Properties on Street Tree Attributes in Singapora. Urban Ecosystems, 19(2): 949-967.

Grabosky, J., and Bassuk, N. (2016) 'Seventeen Years' Growth of Street Trees in Structural Soil Compared with a Tree Lawn in New York City. 16 (2016) 103-109. 
Harris, R.W., Clark, J.R. and Matheny, N.P. (2004). Arboriculture: Integrated Management of Trees Shrubs and Vines. Prentice Hall, Harlow.

Hale, J., Pugh, T., Sadler, J., Boyko, C., Brown, J., Caputo, S., ... Mackenzie, A. (2015). Delivering a Multi-Functional and Resilient Urban Forest. Sustainability, 7(4), 4600-4624. doi: 10.3390/su7044600

Hasan, R., Othman, N., \& Ismail, F. (2016). Roadside Tree Management in Selected Local Authorities for Public Safety. Procedia - Social and Behavioral Sciences, 234, 218-227. doi: 10.1016/j.sbspro.2016.10.237

Hasan, R., Othman, N., \& Ismail, F. (2018). Developing Malaysian Roadside Tree Species Selection Model In Urban Areas. Planning Malaysia Journal, 16(7). doi: 10.21837/pmjournal.v16.i7.515

Jason, G., Nina L. B., P. Trowbridge. (2002). Structural soils: a new medium to allow urban trees to grow in pavement. Landscape architecture technical information series (LATIS). LATIS Cornell University, New York.

JPBD, S. T. and C. D. (2010)."Manual Garis Panduan dan Piawaian Perancangan Negeri Selangor." Retrieved from http://www.jpbdselangor.gov.my

Kadir, M. A. A., \& Othman, N. (2012). Towards a Better Tomorrow: Street Trees and Their Values in Urban Areas. Procedia - Social and Behavioral Sciences, 35, 267-274. doi: 10.1016/j.sbspro.2012.02.088

Kanniah K.D., Ho C.S. (2017) Urban forest cover change and sustainability of Malaysian cities, Chemical Engineering Transactions, 56, 673-678.

Karuppannan S., Baharuddin Z.M., Sivam A., Daniels C.B. (2014). Urban Green Space and Urban Biodiversity: Kuala Lumpur, Malaysia, Journal of Sustainable Development, 7, 1-16.

Lazim, R. M., \& Misni, A. (2016). Public Perceptions towards Tree Risk Management in Subang Jaya Municipality, Malaysia. Procedia - Social and Behavioral Sciences, 222(June), 881-889. https://doi.org/10.1016/i.sbspro.2016.05.210

Leers, M., Moore, G.M. and P.B. May. (2018). Assessment of six indicators of street tree establishment in Melbourne, Australia. Journal of Arboriculture and Urban Forestry: 44:12-22.

Lüttge, U., \& Buckeridge, M. (2020). Trees: structure and function and the challenges of urbanization. Trees. doi: 10.1007/s00468-020-01964-1

Madalena V. M., Phillip H., Kieron J D. (2019). An insight to the current state and sustainability of urban forests across Great Britain based on i-Tree Eco surveys, Forestry: An International Journal of Forest Research, Volume 93, Issue 1, January 2020, Pages 107-123, https://doi.org/10.1093/forestry/cpz054

Murad (2000). Hazard Evaluation of Mature Urban Trees in Kuala Lumpur.Unpublished Master thesis. Universiti Putra Malaysia.

Morgenroth, Justin. (2008). A Review of Root Barrier Research. Arboriculture \& Urban Forestry. 34(2):84-88.

National Landscape Policy (2011).Garis Panduan Landskap Negara

National Parks (2018). Guidelines on Greenery Provision and Tree Conservation for Developments Version 2

Nur Syafiqah, A. S., Abdul-Rahim, A. S., Mohd, J. M. Y., \& Tanaka, K. (2018). An Economic Valuation of Urban Green Spaces in Kuala Lumpur City. Pertanika Journal of Social Sciences \& Humanities (JSSH), 26(1), 469-490 
Ow, L.F.,\& Ghoah, S. (2017). Growth of Street Trees in Urban Ecosystems: Structural Cells and Structural Soil. Journal of Urban Ecology, 3(1).

Pauleit, S. (2003). Urban street tree plantings: Identifying the key requirements. Proceedings of the Institution of Civil Engineers: Municipal Engineer, 156(1), 43-50. doi:10.1680/muen.2003.156.1.43

Paganová, V. (2016). Root System of Trees in Urban Areas. Scientific proceedings of the 5th International Scientific Horticulture Conference. 92-102

PUAC (1997). Services in Streets: A Code for the Placement of Infrastructure Services in New and Existing Streets. Adelaide, SA, Public Utilities Advisory Committee.

Roberts, J.,N. Jackson, and M.Smith (2006). Tree Roots in the Built Environment. Norwich. The Stationary Office.

Saraswat C., Kumar P., Mishra B.K. (2016). Assessment of Storm water Runoff Management Practices and Governance Under Climate Change and Urbanization: An analysis of Bangkok, Hanoi and Tokyo, Environmental Science \& Policy, 64, $101-117$.

Skovsgaard, J. P., Ols, C., \& Mc Carthy, R. (2018). High-pruning of silver birch (Betula pendula Roth): Work Efficiency as a Function of Pruning Method, Pole Saw Type, Slash Removal, Operator, Pruning Height and Branch Characteristics. International Journal of Forest Engineering, 1-11.

Thomas Worthley (2016). Roadside Tree \& Forest Management. Ever source Energy Center

Thomson, J. W. and K. Sorvig (2000). Sustainable Landscape Construction: A guide to green building outdoors. Washington D.C., Island Press.

Urban, J. (1996). "Room to Grow". Landscape Architecture 86(3):74-79 